Brit. J. vener. Dis. (1960), 36, 187.

\title{
INFLUENCE OF METHYL PREDNISOLONE ON THE OUTCOME OF THE TREATMENT OF ACUTE GONORRHOEA IN THE MALE WITH TETRACYCLINE*†
}

\author{
BY \\ R. R. WILLCOX \\ St. Mary's Hospital, London
}

Corticosteroids have been used experimentally in the treatment of syphilis to reduce the Herxheimer reaction, for the lightning pains of tabes dorsalis, and in syphilitic nerve deafness. They have proved their usefulness in the local treatment of interstitial keratitis and in the systemic treatment of the severe allergic reactions which sometimes arise during syphilotherapy with penicillin. They have also been found capable of suppressing symptoms when used in pessary form in trichomonal vaginitis; andalthough not all authors agree-many consider their systemic use of value in the management of Reiter's disease.

Little, however, has been written concerning the effect of steroids in gonococcal or non-gonococcal urethritis. A few authors (e.g. Schulte, Reynolds, and Hammer, 1954) have used hydrocortisone locally in the treatment of non-gonococcal urethritis. Bonner, Lyons, and Shields (1955) and Lyons and Bonner (1957) gave local injections of hydrocortisone in cases of urethral stricture, and claimed successful results in 51 of 56 patients so treated. Willcox (1959) shewed that the outcome of the treatment of nongonococcal urethritis with $4 \mathrm{~g}$. tetracycline phosphate was not affected as regards failure rate or incidence of complications if $64 \mathrm{mg}$. methyl prednisolone was given as well.

It has been shewn experimentally that penicillin and other antibiotics fail to kill phagocytosed gonococci in tissue culture for as long as $\mathbf{4 8}$ hours even when exposed to considerable increase of the minimal inhibitory concentration in vitro (Thayer, Perry, Magnuson, and Garson, 1957). If phagocytosed by fixed tissue cells in sub-epithelial connective tissue, the gonococci might be protected from penicillin and become a source of potential reinfection (Thayer, Perry, Field, and Garson, 1957). It has also been suggested (Reese, 1952) that penicillin may not reach the gonococcus if the organism lies in a closed or intermittently draining focus,

\footnotetext{
* Received for publication August 28, 1959.

+ Paper presented at Tenth Annual Symposium on Recent Advances in the Study of Venereal Diseases, Washington, April, 1959.
}

which may become a source of re-infection if the focus is opened, especially in the female.

In view of the anti-inflammatory properties of steroids it was considered worth while to assess their effect in the antibiotic treatment of gonorrhoea to ascertain whether they could assist the antibiotic to penetrate to the foci of infection. Three possible methods suggested themselves:

(1) A comparison of the complication rate of acute gonorrhoea treated with antibiotics with and without steroids;

(2) A comparison of the resolution rate;

(3) A comparison of the failure rate in two similar groups.

Complications of gonorrhoea are to-day so uncommon that the numbers required to be treated in order to compare the complication rate would be too large to be practicable. The principal difficulty in comparing the resolution rate is in the measurement of progress. Purely clinical observations of outpatients is not enough, as the apparent presence or absence of a small residual discharge may depend on many factors, including the time of day and the period since urine was last voided. Observations on the number of pus cells in smears suffer from the same limitations. Moreover, if conditions are standardized, many of the patients cannot or will not attend at the times proposed for examination. In theory the time of disappearance of the gonococci from smears and cultures is the most satisfactory method, but such an investigation would require day-and-night observations of patients in hospital.

For these reasons it was decided to compare the failure rate. A relatively small dose of tetracycline (with and without steroids) was chosen, so that the failure rate with tetracycline alone was likely to be sufficiently high for any beneficial effects of the steroid to become apparent.

\section{Material}

A series of 64 male patients with acute gonorrhoea was used in this study. There were 43 Negroes (38 from the West Indies, three from West Africa, and 
one each from East Africa and the U.S.A.) and, 21 non-Negroes (thirteen from the United Kingdom, six from Eire, and one each from South America and Sweden). Their average age was $28 \cdot 3$ yrs (range 19 to 46 ), $27 \cdot 3$ yrs for the Negroes and 30.8 yrs for the non-Negroes. Seventeen patients were married and 47 were single.

Only sixteen patients had experienced no previous incident of venereal disease, and the remainder had had no less than 138 previous attacks of gonorrhoea, 25 of non-gonococcal urethritis, two of syphilis, two of warts, one of penile boil, one of genital herpes, and two of anxiety-a total of 171 previous incidents. The 43 Negroes had had 142 previous incidents (average 3.3) and the 21 non-Negroes 29 (average 1/4).

The duration of the urethral discharge before the patient came for treatment was 1 to 3 days in 54 cases, 4 to 7 days in nine, and 8 to 14 days in one. 43 patients complained of some dysuria and $21 \mathrm{did}$ not. The infection had apparently been caught from a stranger by 43 patients, from a friend by 17 , and from the wife by three; in one case the source of infection was unknown. The apparent incubation period was 1 to 7 days in fifty cases, 8 to 14 days in six, over 14 days in two, and unknown in six.

All patients were found to have gonococci in the urethral smear before treatment. The Wassermann reaction and V.D.R.L. (or Kahn) tests at the time of treatment were both negative in fifty, the Wassermann negative and the other positive in thirteen cases, and both tests positive in one case. All but one of the fourteen reactive sera came from Negro patients, and were doubtless due to past yaws in some instances. The gonococcal complement-fixation test was carried out on sera from 56 patients; the results were negative in 44 , doubtful in five, positive in six, and anti-complementary in one. All but two of the eleven reactive sera came from Negro patients.

\section{Method}

Once the gonococcus had been isolated by smear examination, each patient was given three capsules by mouth, and an intramuscular injection of $1 \mathrm{ml}$. distilled water. All 64 patients were given tetracycline phosphate equivalent to $750 \mathrm{mg}$. of the hydrochloride, and 32 of them, taken alternately, were also given $12 \mathrm{mg}$. methyl prednisolone. Both the tetracycline alone and the tetracycline plus the steroid were supplied in capsules of identical appearance. It was hoped to observe each patient after 2 to 3 days, and subsequently at $1,2,4,8$, and 12 weeks from treatment. At each visit the urethra was examined, a smear being taken of the discharge, if present, and the urine being observed for haze and threads. It was planned to examine the prostatic secretion at least twice during surveillance and to make final serum tests for syphilis after 3 months. Should re-treatment be required for relapse, reinfection, or non-gonococcal infection, the case was to be considered closed.

\section{Follow-up}

Not all patients attended as requested, and the follow-up actually obtained is shown in Table I. The apparent frequency of short periods of follow-up is accounted for by the large number of re-infections together with a few relapses, which brought the recorded follow-up to an end. The follow-up obtained was similar in both groups of patients.

\section{Results}

The results obtained in the 64 patients are shewn in Table II (opposite); 58 were followed for at least 3 days, and the status of 28 was satisfactory at the last visit. There were eight apparent failures, all but one of which occurred within 2 weeks, and sixteen apparent re-infections, all but two of which were

TABle I

LENGTH OF FOLLOW-UP BY THERAPY AND RACE

\begin{tabular}{|c|c|c|c|c|c|c|c|}
\hline \multirow{2}{*}{$\begin{array}{l}\text { Length of } \\
\text { Follow-up } \\
\text { (days) }\end{array}$} & \multicolumn{3}{|c|}{ Tetracycline plus Methyl Prednisolone } & \multicolumn{3}{|c|}{ Tetracycline Alone } & \multirow{2}{*}{ Grand Total } \\
\hline & Negroes & Non-Negroes & Total & Negroes & Non-Negroes & Total & \\
\hline $\begin{array}{l}0 \\
1-3 \\
4-7 \\
8-14\end{array}$ & $\begin{array}{l}20 \\
18 \\
15 \\
10\end{array}$ & $\begin{array}{r}12 \\
12 \\
10 \\
9\end{array}$ & $\begin{array}{l}32 \\
30 \\
25 \\
19\end{array}$ & $\begin{array}{l}23 \\
20 \\
18 \\
16\end{array}$ & $\begin{array}{l}9 \\
8 \\
6 \\
3\end{array}$ & $\begin{array}{l}32 \\
28 \\
24 \\
19\end{array}$ & $\begin{array}{l}64 \\
58 \\
49 \\
38\end{array}$ \\
\hline $\begin{array}{l}15-21 \\
22-28 \\
30-60 \\
61-90\end{array}$ & $\begin{array}{l}8 \\
8 \\
7 \\
1\end{array}$ & $\begin{array}{r}5 \\
4 \\
3 \\
-\end{array}$ & $\begin{array}{r}13 \\
12 \\
10 \\
1\end{array}$ & $\begin{array}{r}12 \\
9 \\
7 \\
2\end{array}$ & $\begin{array}{l}2 \\
1 \\
1 \\
-\end{array}$ & $\begin{array}{r}14 \\
10 \\
8 \\
2\end{array}$ & $\begin{array}{r}27 \\
22 \\
18 \\
3\end{array}$ \\
\hline
\end{tabular}


noted after 2 weeks. There were also six instances of subsequent non-gonococcal infection. The criteria of relapse or re-infection were unsatisfactory as they depended on the admission or denial of further sexual exposure by the patient. It was seldom possible to secure the attendance of the new consort and to prove that she was infected. The times at which the apparent relapses or re-infections occurred indicated that the assessment made was probably near to the truth.

TABLE II

RESULTS OF TREATING 64 MALE CASES OF ACUTE GONORRHOEA WITH $750 \mathrm{mg}$. TETRACYCLINE WITH AND WITHOUT STEROIDS

\begin{tabular}{|c|c|c|c|c|c|c|}
\hline \multirow{2}{*}{\multicolumn{2}{|c|}{$\begin{array}{c}\text { Length of } \\
\text { Follow-up } \\
\text { (days) }\end{array}$}} & \multirow{2}{*}{$\begin{array}{c}\text { No. } \\
\text { Fol- } \\
\text { lowed }\end{array}$} & \multicolumn{3}{|c|}{ Result } & \multirow{2}{*}{$\begin{array}{c}\text { Non- } \\
\text { gonococca } \\
\text { Infection }\end{array}$} \\
\hline & & & $\begin{array}{c}\text { Satis- } \\
\text { factory }\end{array}$ & Failures & $\begin{array}{c}\mathrm{Re}- \\
\text { infections }\end{array}$ & \\
\hline \multicolumn{2}{|c|}{$\begin{array}{c}0 \\
1-3 \\
4-7 \\
8-14\end{array}$} & $\begin{array}{l}64 \\
58 \\
49 \\
38\end{array}$ & $\begin{array}{l}7 \\
6 \\
5\end{array}$ & $\begin{array}{c}\overline{2} \\
2 \\
3\end{array}$ & $\bar{z}$ & $\begin{array}{c}\overline{-} \\
\overline{3} \\
1\end{array}$ \\
\hline \multicolumn{2}{|c|}{$\begin{array}{l}15-21 \\
22-28 \\
30-60 \\
61-90\end{array}$} & $\begin{array}{r}27 \\
22 \\
18 \\
3\end{array}$ & $\begin{array}{l}2 \\
2 \\
4 \\
2\end{array}$ & $\underline{z}$ & $\begin{array}{l}2 \\
2 \\
9 \\
1\end{array}$ & $\bar{z}$ \\
\hline \multirow{2}{*}{$\begin{array}{l}\text { Total } \\
\text { Fol- } \\
\text { lowed }\end{array}$} & No. & 58 & 28 & 8 & 16 & 6 \\
\hline & $\begin{array}{l}\text { Per } \\
\text { cent. }\end{array}$ & 100 & $48 \cdot 3$ & $13 \cdot 8$ & $27 \cdot 6$ & $10 \cdot 3$ \\
\hline
\end{tabular}

The effects of the two preparations are compared in Table III, in which the Negro and non-Negro groups are considered separately.

It is evident that, when re-infections are excluded, there is little to choose between the failure rates encountered in Negroes and non-Negroes, or between the results obtained with the two preparations. No adverse side-effects were reported and no complications due to the gonorrhoea occurred in patients treated with either preparation.

\section{Summary and Conclusions}

(1) The available information concerning the effects of steroids in the treatment of gonorrhoea is scanty.

(2) The results of treating 64 male cases of uncomplicated acute gonorrhoea with $750 \mathrm{mg}$. of tetracycline phosphate in a single dose, alternately with and without $12 \mathrm{mg}$. methyl prednisolone, are compared. Both preparations were given orally in capsules of identical appearance.

(3) Of the 32 patients given tetracycline alone, 28 were followed; excluding probable re-infections, there were four failures $(14 \cdot 3$ per cent.). Of the 32 patients given tetracycline phosphate plus methyl prednisolone, thirty were followed; excluding probable re-infections, there were again four failures (13.3 per cent.). No significant difference in the relapse rate was noted between Negro and nonNegro patients.

(4) No adverse side-effects were reported and no complications of gonorrhoea were noted in either series.

(5) It is concluded that, in the doses given, methyl prenisolone had no effect on the course of gonorrhoea treated with tetracycline.

Grateful thanks are expressed to Dr. H. A. Tucker of the Upjohn Company of Kalamazoo, Michigan, U.S.A., for providing the tetracycline and tetracycline/prednisolone preparations used in this study.

\section{REFERENCES}

Bonner, C. D., Lyons, M. K., and Shields, D. (1955). New Engl. J. Med., 253, 130 .

Lyons, M. K., and Bonner, C. D. (1957). J. Urol. (Baltimore), 77, 741 Rees, E. (1952). Brit. J. vener. Dis., 28, 115.

Schulte, T. L., Reynolds, L. R., and Hammer, H. J. (1954). Calif. Med. 80,380 .

Thayer, J. D., Perry, M. I., Magnuson, H. J., and Garson, W. (1957). Antibiot. and Chemother., 7, 311 .

, Field, F., W., and Garson, W. (1957). "Antibiotics Annual, 1956-7", ed. H. Welch and F. Marti-Ibañes, p. 513 Medical Encyclopedia, New York.

Willcox, R. R. (1959). Urol. int. (Basel), 9, 329.

TABLE III

COMPARISON OF RESULTS WITH TETRACYCLINE ALONE AND WITH STEROIDS, BY RACE

\begin{tabular}{|c|c|c|c|c|c|c|c|c|}
\hline \multirow[b]{2}{*}{ Drug } & \multirow[b]{2}{*}{ Race } & \multirow{2}{*}{$\begin{array}{c}\text { No. } \\
\text { Treated }\end{array}$} & \multirow{2}{*}{$\begin{array}{l}\text { No. } \\
\text { Followed }\end{array}$} & \multicolumn{3}{|c|}{ Result } & \multirow{2}{*}{$\begin{array}{c}\text { Non- } \\
\text { gonococcal } \\
\text { Infection }\end{array}$} & \multirow{2}{*}{$\begin{array}{l}\text { Per cent. } \\
\text { Failures } \\
\text { of Those } \\
\text { Followed }\end{array}$} \\
\hline & & & & Satisfactory & Failures & $\begin{array}{c}\text { Re- } \\
\text { infections }\end{array}$ & & \\
\hline \multirow[t]{2}{*}{ Tetracycline Alone .. } & $\begin{array}{l}\text { Negro } \\
\text { Non-Negro }\end{array}$ & $\begin{array}{r}23 \\
9\end{array}$ & $\begin{array}{r}20 \\
8\end{array}$ & $\begin{array}{l}6 \\
4\end{array}$ & $\begin{array}{l}3 \\
1\end{array}$ & $\begin{array}{l}9 \\
1\end{array}$ & $\frac{2}{2}$ & $\begin{array}{l}15 \cdot 0 \\
12 \cdot 5\end{array}$ \\
\hline & Total & 32 & 28 & 10 & 4 & 10 & 4 & $14 \cdot 3$ \\
\hline \multirow{2}{*}{$\begin{array}{l}\text { Tetracycline plus } \\
\text { Methyl Prednisolone }\end{array}$} & $\begin{array}{l}\text { Negro } \ldots . . \\
\text { Non-Negro }\end{array}$ & $\begin{array}{l}20 \\
12\end{array}$ & $\begin{array}{l}18 \\
12\end{array}$ & $\begin{array}{r}12 \\
6\end{array}$ & 2 & $\begin{array}{l}3 \\
\mathbf{3}\end{array}$ & 1 & $\begin{array}{l}11 \cdot 1 \\
16 \cdot 7\end{array}$ \\
\hline & Total & 32 & 30 & 18 & 4 & 6 & 2 & $13 \cdot 3$ \\
\hline
\end{tabular}


Influence de la méthyle-prednisolone sur le résultat du traitement de la blennorragie aiguë du mâle par la tetracycline

\section{Résumé et conclusions}

(1) On a peu de renseignements concernant les effets des stéroïdes dans le traitement de la blennorragie.

(2) On compare les résultats chez 64 malades atteints de blennorragie aiguë fruste, traités par une seule dose de $750 \mathrm{mg}$. de phosphate de tetracycline à laquelle, dans chaque deuxième cas, on avait ajouté $12 \mathrm{mg}$. de prednisolone méthylique. Les deux préparations étaient administrées par voie buccale sous forme de capsules d'apparence identique.
(3) Sur 32 malades traités par la tetracycline seule, 28 ont été suivis; après l'exclusion des ré-infections probables, il y avait quatre échecs $(14,3 \%)$. Sur les 32 malades traités par le phosphate de tetracycline et la prednisolone méthylique, 30 ont été suivis; après l'exclusion des ré-infections probables, il y avait de nouveau 4 échecs $(13,3 \%)$. On n'a pas trouvé de différence appréciable entre les taux des rechutes chez les malades de race blanche et noire.

(4) Dans aucun groupe on n'a noté de réactions toxiques ni de complications de la blennorragie.

(5) On conclut que, en dose administrée, la prednisolone méthylique n'a pas d'effet sur l'évolution de la blennorragie traitée par la tetracycline. 